В. О. Коробчанський, Ю. К. Резуненко, О. І. Герасименко, Н. М. Кателевська, О. С. Богачова

Харківський національний медичний університет

\title{
АКТУАЛЬНІ ПИТАННЯ ФОРМУВАННЯ МОТИВАЦІЇ ДО НАВЧАННЯ У СТУДЕНТІВ ХАРКІВСЬКОГО НАЦІОНАЛЬНОГО МЕДИЧНОГО УНIВЕРСИТЕТУ
}

\author{
V. O. Korobchanskyi, Yu. K. Rezunenko, O. I. Herasymenko, N. M. Katelevska, \\ O. S. Bohachova \\ Kharkiv National Medical University

\section{ACTUAL QUESTIONS OF FORMATION OF STUDY MOTIVATION IN STUDENTS OF KHARKIV NATIONAL MEDICAL UNIVERSITY}

\begin{abstract}
Мета роботи - провести аналіз умов формування мотивації до навчання студентів Харківського національного медичного університету (далі - ХНМУ) з вивченням методичних підходів до ії формування. Визначити особливості формування мотивації до навчальної діяльності студентів, які засвоюють дисципліну “Гігієна та екологія”. Окрему увагу приділити питанню факторів ризику формування навчальної мотивації іноземних студентів, які навчаються в ХНМУ.

Основна частина. Експериментальна перевірка умов формування мотивації до пізнавальної діяльності в студентів показала низький рівень сформованості мотивації до пізнавальної діяльності в іноземних студентів, які навчаються російською мовою під час оволодіння знаннями з дисципліни “Гігієна та екологія”. Наслідком цього є нижчий бал поточної успішності студентів, що свідчить про гірший рівень засвоєння знань з дисципліни. Відповідне становище обумовлене недостатнім рівнем усвідомлення значущості набутих знань у подальшій професійній діяльності, а також недостатнім рівнем володіння мовою навчання.

Висновки. Умови формування мотивації до пізнавальної діяльності у студентів-іноземців ХНМУ, які навчаються російською мовою, потребують удосконалення традиційних методів формування мотивації до навчання та впровадження новітніх педагогічних методик при вивченні дисципліни “Гігієна та екологія”, що сприятиме зростанню рівня засвоєння навчального матеріалу. Слід зазначити, що окремої уваги потребує загальна специфіка студентів-іноземців, яка вимагає більшої уваги викладачів до навчальних та виховних заходів.
\end{abstract}

Ключові слова: пізнавальна мотивація; навчання; студенти; медична освіта; вища школа.

The aim of the work - to analyze formation conditions of study motivation of students of Kharkiv National Medical University (hereinafter the KhNMU); to study methods of formation of students' learning motivation in studying the discipline of Hygiene and Ecology; to determine peculiarities of the formation of motivation for the students' educational activity. Particular attention should be paid to the issue of risk factors for the formation of academic motivation of foreign students studying at the KhNMU.

The main body. Experimental testing of the conditions for the formation of motivation for cognitive activity among students showed a low level of that parameter in foreign students. Data of study show worse level of mastery of discipline knowledge. The relevant situation is due to the insufficient level of awareness of the acquired knowledge's significance in further professional activities. The main reasons for this situation are the low level of knowledge of the significance of the knowledge gained during the study of the discipline of Hygiene and Environment in future professional activities; as well as problems during the studies that are associated with a lack of knowledge of the Russian language.

Conclusions. Conditions for the formation of educational motivation of foreign students need to improve existing teaching methods, which will increase the level of mastering the discipline of Hygiene and Environment. It is necessary to note that special attention should be paid to the general specificity of foreign students, which requires more attention of teachers to educational and educational activities.

Key words: motivation; education; students; medical education; high school.

Вступ. Постійна модернізація освітньої системи вищих навчальних закладів України та розширення обсягу надання платних навчальних послуг висувають нові вимоги і критерії до професійної підготовки студентів, зокрема студентів-іноземців.

(C) В. О. Коробчанський, Ю. К. Резуненко, О. І. Герасименко та ін.
Специфічні риси сучасної медичної освіти характеризуються зростанням географічної мобільності студентів. Наслідком цього є збільшення кількості іноземних студентів у вишах України. Відповідне становище висуває особливі вимоги до якості та професійної придатності знань, що отримують 
студенти під час навчання. Адже це є одним із первинних факторів конкурентоспроможності вищого навчального закладу. Водночас якість отриманих знань обумовлена тим, як студенти засвоюють систему знань, що їм пропонується як навчальний матеріал. При цьому основним фактором успішності оволодіння знаннями стає наявність у них мотивації до пізнавальної діяльності. Окреме місце в цій системі займає формування професійної мотивації студента, що є основою професійної конкурентоспроможності.

Вивчення психолого-педагогічної літератури свідчить про те, що мотиваційний аспект діяльності протягом останніх років є предметом пильної уваги багатьох вчених, як вітчизняних, так і зарубіжних. Мотивацію як психологічну категорію досліджували А. О. Кірсанов, С. Л. Рубінштейн, В. С. Мерлін та інші [3, 4, 7]. 3 розвитком теорії навчальної діяльності збагатилася новим змістом і концепція мотивації навчання. Мотиви навчальної діяльності розглядали Г. І. Щукіна, Ф. К. Савіна, В. С. Ільїн [1, 2, 5]. Ряд вчених (А. О. Вербицький, М. О. Данилов та інші) досліджували різні засоби впливу педагога на розвиток мотиваційно-пізнавальної сфери осіб, які навчаються [6].

Однак стосовно вищої медичної школи проблема формування мотивації пізнавальної діяльності студентів, особливо студентів-іноземців, незважаючи на ії важливість і актуальність, залишається недостатньо дослідженою. Таким чином, виявляється протиріччя між об’єктивною необхідністю формування мотивації пізнавальної діяльності студентів медичного ВНЗ шляхом впровадження інтерактивних технологій, яка б враховувала як внутрішні особливості навчання, так і зовнішні вимоги до фахівців медичного профілю з вищою освітою - з одного боку, і відсутністю науково обгрунтованої технології формування мотивації пізнавальної діяльності студентів медичного ВНЗ за допомогою новітніх систем - 3 іншого. Відповідне становище зумовлює актуальність дослідження методики формування мотивації до пізнавальної діяльності студентів у процесі навчання дисципліни “Гігієна та екологія” у Харківському національному медичному університеті.

Мета роботи - визначення актуальних питань формування мотивації до пізнавальної діяльності у студентів Харківського національного медичного університету на прикладі засвоєння дисципліни “Гігієна та екологія”.

Основна частина. Експериментальна перевірка умов формування мотивації до пізнавальної діяль- ності у студентів була проведена із залученням студентів, які проходять навчання дисципліни “Гігієна та екологія” на кафедрі гігієни та екології № 1 Харківського національного медичного університету.

До участі у дослідженні було залучено 60 студентів 2 курсу стоматологічного факультету, а саме 30 студентів-іноземців російськомовної форми навчання та 30 вітчизняних студентів. Під час дослідження вивчали питання особливостей сприйняття навчального матеріалу студентами груп порівняння, визначення рівнів мотивації до оволодіння дисципліною, дані поточної успішності студентів, як показники рівня засвоєння дисципліни.

Було застосовано анкетні методи опитування, зокрема, з метою вивчення ставлення студентів до навчального процесу було розроблено анкету, що включала відповідні питання. А саме, з метою встановлення особливостей сприйняття навчання студентами, їм було запропоновано відповісти на такі питання: чи подобається Вам навчання та організація навчального процесу в ХНМУ; чи є викладання навчальних дисциплін у ХНМУ послідовним; чи є у Вас складнощі у розумінні мови викладання; чи легко Вам засвоювати теоретичний матеріал без наглядного супроводу; чи зацікавлені Ви у вивченні дисципліни “Гігієна та екологія"; чи зможете Ви застосовувати знання, набуті під час вивчення дисципліни “Гігієна та екологія”, у Вашій майбутній практичній діяльності.

Експериментальна перевірка умов формування мотивації до пізнавальної діяльності у студентів 2 курсу дозволила встановити найбільш значущі фактори, що її обумовлюють.

Так, на питання “Чи подобається Вам навчання в ХНМУ?” 86,67 \% студентів-іноземців та 93,33 \% вітчизняних студентів відповіли позитивно. Щодо питання про організацію умов навчання лише 43,33 \% студентів-іноземців та 53,33 \% вітчизняних студентів висловилися позитивно. Слід зауважити, що 53,33 \% іноземних та 66,67 \% українськомовних студентів відзначають непослідовність викладання дисциплін під час навчання.

Особливе занепокоєння викликає формування взаємовідносин між студентами у досліджуваних групах. Так, на питання “Чи вважаєте Ви стосунки у Вашій групі добрими?” та “Ви вважаєте свою групу єдиним цілим?” студенти відповіли негативно у 63,33 \% та 86,67 \% відповідно.

Відносно ставлення студентів до вивчення дисципліни "Гігієна та екологія” та практичного значення набутих знань встановлено, що лише 23,33 \% 
іноземних студентів вважають отримані знання корисними для майбутньої практичної діяльності. Відповідний показник вітчизняних студентів становить 63,33 \%. Проте зацікавленість вітчизняних студентів у вивченні зазначеної дисципліни є значно вищою і становить 86,67 \% на відміну від 36,67 \% відповідної зацікавленості іноземних студентів. Це свідчить про більш значущий рівень мотиваційної спрямованості вітчизняних студентів.

Окремої уваги потребує той факт, що 73,33 \% студентів-іноземців мають проблеми із розумінням мови викладання дисципліни, відповідне становище призводить до того, що у разі відсутності наглядного супроводу лише 26,67 \% іноземних студентів здатні засвоїти теоретичний матеріал на відміну від 93,33 \% вітчизняних студентів. Показники формування внутрішньогрупових взаємовідносин свідчить про гірше становище студентів-іноземців. Так, на питання “Чи вважаєте Ви стосунки у Вашій групі добрими?”, що також входило до анкети, студенти-іноземці відповіли позитивно у 36,67 \% випадків на відміну від 93,33 \% студентів вітчизняної форми навчання.

Визначення рівнів формування мотиваційно-пізнавальної діяльності у студентів обох груп показало, що лише 10,00 \% студентів-іноземців мають високий рівень пізнавального мотиву, відповідно, 56,67 \% та 33,33 \% осіб - середній та низький. Показники рівня формування пізнавальної діяльності вітчизняних студентів свідчать, що високий рівень мають 63,33 \% респондентів, середній та низький 33,33 \% та 3,34 \% відповідно.

Показники середньої успішності студентів становлять 3,11 та 3,69 бали відповідно у студентівіноземців та студентів вітчизняної форми навчання.

\section{Список літератури}

1. Гилюн О. В. Освітні мотивації студентської молоді / О. В. Гилюн // Грані: наук.-теорет. і громад.-політ. альманах / Дніпроп. нац. ун-т ім. О. Гончара, Центр соц.-політ. дослідж. - Д., 2012. - № 1 (81). - С. 102-104.

2. Дусавицкий А. К. Развитие личности в студенческом коллективе в зависимости от сформированности учебно-профессиональных интересов : учебно-методическое пособие / А. К. Дусавицкий. - Х. : ХНУ имени В. Н. Каразина, 2012. - 32 с.

3. Макаревич О. Мотивація як підгрунтя дій особистості / О. Макаревич // Соціальна психологія. - 2006. № 2 (16). - С. 134-141.

4. Подоляк Л. Г. Психологія вищої школи : підруч. / Л. Г. Подоляк, В. І. Юрченко. - [3-тє вид., випр. і доповн.]. - К. : Каравела, 2008. - 352 с.
Таким чином, за встановленими результатами ми можемо зробити висновок про низький рівень сформованості мотивації до пізнавальної діяльності в іноземних студентів, які навчаються російською мовою під час оволодіння знаннями 3 дисципліни “Гігієна та екологія". Наслідком цього є нижчий бал поточної успішності студентів, що свідчить про гірший рівень засвоєння знань 3 дисципліни.

Основними причинами відповідного становища $€$ низький рівень усвідомлення значення знань, набутих під час навчання дисципліни “Гігієна та екологія”, в майбутній професійній діяльності; а також проблеми під час навчання, що пов’язані 3 недостатнім рівнем володіння російською мовою. Окремого значення набувають фактори, що пов’язані з важкістю у формуванні міжособистісних взаємовідносин у студентському середовищі.

Висновки. Зниження ефективності традиційних методик навчання, яке спостерігається при розгляданні особливостей навчальної діяльності студентів, вимагає корекції та впровадження сучасних інноваційних методик навчання, наприклад ділової гри або кейс-методу. Удосконалення методів формування мотивації до навчання сприятиме зростанню рівня засвоєння навчального матеріалу. Слід зазначити, що окремої уваги потребує загальна специфіка студентів-іноземців, яка вимагає більшої уваги викладачів до навчальних та виховних заходів.

Особливо важливим цей аспект постає при формуванні співвідношень викладача вищого медичного закладу зі студентами-іноземцями, для яких існування мовного бар’єра, непорозуміння окремих дисциплінарних вимог та традиційних форм вивчення дисциплін є факторами, які ускладнюють процес оволодіння навчальним матеріалом.

5. Семиченко В. А. Проблемы мотивации поведения и деятельности человека / В. А. Семиченко // Модульный курс психологии. Модуль “Направленность” (Лекции, практические занятия, задания для самостоятельной работы). - К. : Миллениум, 2004. - 521 с.

6. Слепкань 3. I. Наукові засади педагогічного процесу у вищій школі / 3. І. Слепкань ; Міністерство освіти та науки України, Національний педагогічний ун-т ім. М. П. Драгоманова. - К. : НПУ, 2000. - С. 138-173.

7. Фіцула М. М. Основи психології і педагогіки : посібник / М. М. Фіцула, О. М. Степанов. - К. : Академвидання, 2003. - 504 с. 


\section{References}

1. Hyliun, O.V. (2012). Osvitni motyvatsii studentskoi molodi [Educational motivation of student youth]. Hrani: nauk.-teoret. i hromad.-polit. almanakh-Borders: Scientific Theoretical and Public Political Almanac, 1 (81), 102-104 [in Ukrainian].

2. Dusavitskyy, A.K. (2012). Razvitiye lichnosti v studencheskom kollektive $v$ zavisimosti ot sformirovannosti uchebno-metodicheskoye posobiye [Development of the personality in the student collective, depending on the formation of educational and professional interests: Educational and methodical manual]. Kharkiv: KhNU named after V.N. Karazin [in Russian].

3. Makarevych, O. (2006). Motyvatsiia yak pidhruntia dii osobystosti [Motivation as the basis for the actions of the individual]. Sotsialna psykholohiia - Journal of Social Psychology, 2 (16), 134-141 [in Ukranian].
4. Podoliak, L.H., \& Yurchenko, V.I. (2008). Psykholohiia vyshchoi shkoly [Psychology of higher education]. Kyiv: Karavela [in Ukrainian].

5. Semichenko, V.A. (2004). Problemy motivatsii povedeniya i deyatelnosti cheloveka [Problems of motivation of human behavior and activities]. Modular course in psychology. Module “Directionality”. Kyiv: Millenium [in Russian].

6. Slepkan, Z.I. (2005). Naukovi zasady pedahohichnoho protsesu u vyshchii shkoli [Scientific principles of pedagogical process in high school]. Ministry of Health of Ukraine. National Pedagogical University by M.P. Drahomanov. Kyiv: NPU [in Ukrainian].

7. Fitsula, M.M., \& Stepanov, O.M. (2003). Osnovy psykholohii i pedahohiky: Posibnyk [Fundamentals of psychology and pedagogy. Textbook]. Kyiv:Akademvydannia [in Ukrainian]. 